\title{
The moderating effect of demographic characteristics on the relationship between strategic capabilities and firm performance in women-owned entrepreneurial ventures in Nairobi, Kenya
}

\author{
Joyce Kimosop* \\ Moi University \\ Michael Korir \\ Moi University
}

\author{
Margaret White \\ Oklahoma State University
}

\begin{abstract}
This study is motivated by the need to understand the determinants of performance in women-owned enterprises. We examine the relationship between strategic capabilities and firm performance with demographic characteristics as moderators in women-owned enterprises in Nairobi, Kenya. Results show that strategic capabilities have a significant effect on the overall performance. Further, IT capabilities and technological capabilities have a positive and significant relationship with performance. Only age has a negative and significant moderating effect. We recommend enhancement of technological capabilities among women entrepreneurs so that they can better direct their capabilities toward firm performance. Copyright (C) 2016 ASAC. Published by John Wiley \& Sons, Ltd.
\end{abstract}

Keywords: strategic capabilities, women entrepreneurship, firm, performance

\begin{abstract}
Résumé
Cette étude est motivée par le désir de mieux comprendre les déterminants de la performance dans les entreprises appartenant à des femmes. À partir d'entreprises appartenant à des femmes basées à Nairobi au Kenya, l'étude examine la relation entre les capacités stratégiques et la performance en utilisant les caractéristiques démographiques comme modératrices. Les résultats montrent que les capacités stratégiques ont un impact important sur la performance globale. Par ailleurs, les capacités en IT et les capacités technologiques entretiennent une relation positive et significative avec la performance. Seul l'âge a un effet modérateur négatif et significatif sur la performance. Nous proposons aux femmes entrepreneures d'améliorer leurs capacités technologiques afin de mieux orienter leurs aptitudes vers la performance de leurs entreprises. Copyright (C) 2016 ASAC. Published by John Wiley \& Sons, Ltd.
\end{abstract}

Mots-clés : capacités stratégiques, entrepreneuriat féminin, firme, performance
Women represent a significant portion of entrepreneurs who impact the global economy. In both developed and developing economies, the growth and participation of women in entrepreneurship has been noted. Women's participation has contributed significantly to the socio-economic growth

*Please address correspondence to: Dr. Joyce Kimosop, Department of Marketing and Management, Moi University, P.O. Box 3900 - 3100, Eldoret, Kenya. Email: joycekomen@yahoo.com of their respective countries by introducing innovations as well as creating employment and wealth. The phenomenon of women entrepreneurship has thus gained importance in both practice and academia (Jennings \& Brush, 2013; Verheul, Van Stel, \& Thurik, 2006)

Much research on women entrepreneurship has focused on individual characteristics and gender-specific barriers to entrepreneurship as predictors of firm performance (Catley \& Hamilton, 1998). These studies have 
focused on the characteristics, motivations, and challenges of women entrepreneurs. Relatively few studies have focused on the strategy and structure of women-owned enterprises (Brush, 1992). Mukhtar (2002) noted that gender related research in general and the study of management characteristics, structures, and strategies employed by women business owners in particular has not kept pace with changes in the small firms sector.

Additionally, Carter and Allen (1997), in their study on size determinants of women-owned businesses, noted that women should not be considered a homogenous group. Stevenson (1990) supports this view and noted that as women entrepreneurs are not a homogenous group, efforts should be made to develop typologies that consider their diversity. Few studies have focused on women entrepreneurs exclusively (Brush \& Cooper, 2012) and it is an understudied field (De Bruin, Brush, \& Welter, 2007) needing more examination.

Furthermore, most research focusing on women entrepreneurs has occurred in developed countries (Hisrich, Brush, Good, \& DeSouza, 1997; Lerner, Brush, \& Hisrich, 1997). Limited knowledge exists on women entrepreneurs in developing countries (Idris, 2009). Studies conducted in developed countries with individualized cultural orientations may not be generalizable to the developing countries and more specifically the African context (De Bruin et al., 2007; Mungai \& Ogot, 2012). Additionally, according to the GEM 2012 report (Kelley, Brush, Greene, \& Litovsky, 2013), there are relatively more entrepreneurial women in developing countries and therefore there is a greater potential for higher impact on their economies (Brush \& Cooper, 2012). As such, gaining insight into the phenomenon of women entrepreneurship in developing countries is vital.

The justification of this study is three-fold: First, it enhances the understanding of the determinants of firm performance in women-owned entrepreneurial ventures by extending theory and knowledge of strategic management into women-owned enterprises. It also makes a valuable contribution to the entrepreneurship literature by providing knowledge about the capabilities of women entrepreneurs in developing economies. Secondly, due to the crucial role played by women entrepreneurs in the economic development of many nations, many policy makers and researchers are paying greater attention to the growth of women entrepreneurship (Fuentes-Fuentes, Bojica, Ruiz-Arroyo, \& Welter, 2015). This study therefore sheds more light on the factors that determine the performance of women-owned entrepreneurial ventures. Policy makers will use the findings and recommendations from this study as guidelines to make crucial decisions. Finally, the knowledge gained from this study would be useful for researchers as a point of reference and can also pave the way for further empirical investigations into the women entrepreneurship phenomenon.

\section{Background and Hypotheses}

\section{Firm Performance in Women-Owned Entrepreneurial Ventures}

The performance of women-owned businesses has become an important area of concern for policy makers and a subject for much academic debate. The concern has been the underperformance of women-owned businesses (Orser \& Hogarth-Scott, 2002). Studies have revealed that women-owned firms are more likely to have lower levels of sales, profits, and employment and eventually close their doors (Kallenberg \& Leicht, 1991; Rosa, Carter, \& Hamilton, 1996). Relatively little is known about why women-owned firms underperform (Fairlie \& Robb, 2009). Previous studies on differences in firm performance by gender found that financial capital, education, and work experience may be important factors. Another view from previous research is that women access different business and investment networks and this could affect the outcomes of women-owned ventures (Brush, Carter, Gatewood, Green, \& Hart, 2004).

To identify underlying causes, we explored the determinants of firm performance in women-owned entrepreneurial ventures from a strategic management perspective. In recent years, the resource based view (RBV) has emerged as a popular perspective for explaining performance (Newbert, 2007). Relying on the traditional strategic management construct of distinctive competence, the RBV suggests that the relative performance of a firm is rooted in the firms' strategic resources (Barney, 1991).

Every organization possesses its own capabilities that enable it to perform the activities necessary to produce its products and services. More successful firms conceivably have capabilities that help them perform their activities better. These capabilities have been termed distinctive competencies or strategic capabilities and generally refer to the unique skills and activities that a firm has over rival firms (Lado, Boyd, \& Wright, 1992; Selznick, 1957). In this study, we adopt Day's (1990) definition of strategic capabilities as "complex bundles of skills and accumulated knowledge that enable firms to coordinate activities and make use of their resources" (Day, p. 38) to create economic value and achieve and maintain better performance (Desarbo, Di Benedetto, Song, \& Sinha, 2005, p. 49). Research has shown that strategic capabilities are critical to the success of a business. This study posits that the strategic capabilities of women-owned entrepreneurial ventures could explain firm performance.

\section{Strategic Capabilities and Firm Performance}

Desarbo et al. (2005) have identified the dimensions of strategic capabilities in firms as marketing capabilities, market-sensing capabilities, technology capabilities, information technology capabilities, and management 
capabilities. They suggest that technological capabilities are those concerned with the production of goods and logistics that allow the firm to either differentiate its product or keep costs down. Market sensing capabilities are concerned with customers and channels, and connected to changing customer needs (i.e., sensing market trends). Marketing capabilities include skills in segmentation and target-pricing advertising that enable the firm to implement effective marketing programmes. Information technology capabilities are those that help the firm diffuse market information effectively across all relevant functional areas. Management capabilities are those that support all other capabilities including human resource management, financial management, and others.

These categories of capabilities are common to many organizations and have been identified and used in prior research (Day, 1994; Desarbo et al., 2005; Song, Nason, \& Di Benedetto, 2008). While not all organizations have these capabilities (Day, 1994; Day \& Wensley, 1988; Song et al., 2008), how managers/owners develop these capabilities within their businesses explains differentials in performance.

\section{Strategic Capabilities in Women-Owned Entrepreneurial Ventures and Firm Performance}

Loscocco and Robinson (1994) found in their research that women-owned businesses are concentrated in the retail trade and service sector, while men-owned firms are more concentrated in the manufacturing, construction, and high technology fields. Cejka and Eagly (1999) attributed this to gender stereotyping. In their study, they examined the role of gender stereotypes and found that to the extent that occupations were female dominated, feminine personality or physical attributes were thought essential for women's success; to the extent that occupations were male dominated, masculine personality or physical attributes were thought more essential for success.

In the context of this study where a particular industry sector required feminine personality traits as well as feminine physical and cognitive attributes such as those that are affectionate, nurturing, cooperative, imaginative, and artistic among others, we expected a woman entrepreneur to perform better because of the gender/industry fit. Cejka and Eagly (1999) posited that the gender-industry fit would enable owners to effectively use inherent capabilities to accomplish the tasks at hand. Social role theory, in which this study is anchored, considers the structural account of gender-based differences in human behaviour. This theory postulates that men and women behave according to the stereotypes associated with the social roles they occupy. Eagly and Wood (1999) noted that because men and women tend to occupy different social roles, they become psychologically different in ways that adjust them to these roles. That is to say, women in general are considered more communal and men as more agentic. The communal role, characterized by attributes such as nurturance, connectedness, kindness, and emotional expressiveness, is commonly associated with domestic activities, and by extension, with women. The agentic role, characterized by attributes such as assertiveness, aggressiveness, autonomy, courage, and independence, is commonly associated with public activities, and by extension, with men. Behaviour is strongly influenced by gender roles when cultures endorse gender stereotypes and form firm expectations based on those stereotypes (Eagly, 1987)

Market-linking capabilities and firm performance. Many scholars have noted that a firm's ability to sense and seize market opportunities and to readjust their resources accordingly impacts performance (Day, 2000; Eisenhardt \& Martin, 2000; Teece, Pisano, \& Shuen, 1997; Zahra, Sapienza, \& Davidsson, 2006). This capability develops market intelligence in terms of current customer needs and in terms of disseminating and responding to the information within the organization (Kohli, Jaworski, \& Kumar, 1993). Reijonen and Komppula (2010), in their study of SMEs in Finland, found that customer orientation and market intelligence were important success factors in the performance of SMEs. Because nurturing and strong communication skills are viewed as feminine, we hypothesize:

H1: Women-owned businesses with strong marketlinking capabilities will perform significantly better than those with weak market-linking capabilities.

Technological capabilities and firm performance. Technological capability is the ability to use technological resources to create value. A technological capability has been defined as "the ability to perform any relevant technical function or volume activity within the firm including the ability to develop new products and processes and to operate facilities effectively" (Teece et al., 1997, p. 521). Technological capability, while key in all businesses, has greater relevance in the manufacturing sector. Women are not traditionally employed in the manufacturing sector, nor are they perceived to be dominant in the field of technology. It is perceived that the manufacturing sector and the related needed capability to manage such a venture is more suited to the male gender role. Therefore:

H2: The level of technological capability will not be significantly related to performance in women-owned businesses.

Marketing capabilities and firm performance. Marketing capabilities include skills such as segmenting and targeting markets, advertising, pricing, and integrating marketing activities (Day, 1990; Desarbo et al., 2005: Song et al., 2008). Marketing activities include market planning, revenue forecasting, and allocation of resources. The organization needs to communicate its products' unique advantages to enhance competitiveness through customer satisfaction and loyalty. 
Studies on the marketing practices of small businesses, especially women-owned enterprises, have been few. Blankson and Omar (2002) found that most firms practice informal marketing deliberations that rely on the intuition and energy of the entrepreneur. Van Auken, Rittenburg, Doran, and Hsieh (1994) conducted an empirical analysis of advertising by 121 women-owned enterprises and found that women entrepreneurs tend to use referrals, community events, telephone directories, and fliers more than a general sample of small business owners. They attributed this to differences in women's communication style and the value women place on personal forms of communication - market linking capabilities. As such, we hypothesize:

H3: The level of marketing capabilities will not be significantly related to performance in women-owned businesses.

Information technology capabilities and firm performance. IT capabilities facilitate internal communication and cross-functional integration in firms (Song et al., 2008). A firm with better IT capabilities performs better and has greater organizational success (Nuevo \& Wade, 2010). This is especially the case if IT is used creatively to deliver superior value to the customer (Peltier, Schibrowsky, $\&$ Zhao, 2009). Studies have shown that using IT creatively enhances performance and also ensures better crossfunctional transmission leading to more successful new products and generally improved competitiveness (Bharadwaj, 2000; Dehning \& Stratopoulos, 2003; Song et al., 2008). This is very important for small businesses that must be efficient with their limited resources. Celuch and Murphy (2010) found that small businesses could improve their strategic flexibility through the expanded communication afforded by the internet and through aligning IT to the firms' market orientation. The internet has the market-linking capability that can help a firm manage customer and competitor information and also manage internal activities, thus enabling better performance. Other businesses are able to use a wider range of IT to support both the communication and computerization of aspects of their business-for example, using data software to track and stock their inventory (Tandon, 2002). Since this capability has both the communication aspect that is perceived to fit the female gender role and the technical element that conforms to the male gender role, it is expected that the effect of IT capabilities on firm performance in women-owned business would not be significant. Therefore:

H4: The level of information technology capabilities will not be significantly related to performance in women-owned businesses.

Management capabilities and firm performance. Management is the act of getting individuals to work together to accomplish desired goals and objectives. Management capability involves competence in three areas: ability to coordinate the firm's activities, ability to understand and motivate people, and ability to build a power base and establish the right connections (Chandler \& Jensen, 1992). Women tend to use relational management styles whereas men tend to use more transactional management styles (Idris, 2009). The relational dimension of management style includes collaboration, mutual empowerment, sharing of information, as well as nurturing and empowering in the management of the business (Eagly, 2007; Podsakoff, Mackenzie, Moorman, \& Fetter, 1990). These have been found to significantly benefit long-term business success (Heffernan, 2003).

Women entrepreneurs however, have generally been found to make decisions as well as structure and run their businesses based on intuition more than planning (Mukhtar, 2002). Such an approach can impede their management success. Powell and Ansic (1997) also found that women adopt different strategies in financial decisions and tend to take less risk. This low risk propensity affects their decisionmaking process (e.g., accessing financial resources through taking out loans). It has been found that women who have access to financial resources and have good relationships with their banks tend to perform better (Powell \& Ansic, 1997). Therefore, we hypothesize:

H5: Women-owned businesses with strong management capabilities will perform significantly better than those with weak management capabilities.

\section{Moderating Effect of Demographic Characteristics}

The upper echelon's theory by Hambrick and Mason (1984) postulates that characteristics of top-level managers make a difference in how the organization performs. Hambrick and Mason argued that a manager's characteristics (e.g., demographic characteristics) influence the decisions that they make and therefore the actions adopted by the organizations that they lead. They suggested this is due to demographic characteristics being associated with the many cognitive bases, values, and perceptions that influence the decision making of managers. For this study, therefore, demographic characteristics (age of owner, level of education, and prior experience) of women entrepreneurs are considered moderating variables in the relationship between strategic capabilities and performance. Several studies have assessed the relative effects of the demographic characteristics on firm performance. Brush (1992) has found that individual dimensions such as age, education, and work experience affect performance in women-owned businesses.

Age is one factor found to influence the manner in which decisions are reached within organizations. It has been noted that younger managers are more innovative, take more risks, and are more in touch with current technology 
while older managers are more risk averse and more conservative in decision making (Carlson \& Karlsson, 1970). Therefore:

H6: When the business owner is younger, the relationship between strategic capabilities and firm performance is enhanced.

Level of Education affects performance. Several studies have supported this view (Box, White, \& Barr, 1993; Brush \& Hisrich, 1991; Cooper, 1981; Saffu, Aporu, Elijah-Mensa, \& Ahumatah, 2008). These studies have found that better educated managers are more receptive to new ideas. In addition, because formal education can help one accumulate absorptive capacities such as confidence, knowledge, and skills (Daneels, 2008, p. 525), highly educated entrepreneurs can lead to successful performance. Age and education have both been positively related to firm performance (Birley \& Norburn, 1987). In general, the literature suggests that entrepreneurs in early middle age (35-45 years old at founding) with several years of college perform better than others. Therefore:

H7: When the business owner is highly educated, the relationship between strategic capabilities and firm performance is enhanced.

An entrepreneur's experience is positively correlated to performance (Box et al., 1993; Box, Watts, \& Hisrich, 1994; Cooper, 1981; Yusuf, 1995). Boohene (2009) found that a lack of education and work experience contributed to women owners' inability to manage a business effectively. Less educated women may face increased human capital and financial capital constraints inhibiting their business pursuits (Dolinski, Caputo, Pasumaty, \& Quanzi, 1993). While many studies have looked at the direct effects of demographic characteristics on performance, we posit that age of owner, level of education, and prior experience affect the strategic capabilities of the individual firms and in turn the overall firm performance. Therefore:

H8: When the business owner has a high level of prior experience, the relationship between strategic capabilities and firm performance is enhanced.

The above discussion demonstrates that there are significant differences in the extent to which the specific strategic capabilities influence firm performance in womenowned entrepreneurial ventures. These differences, as explained by social role theory, are perceived to be influenced by gender stereotyping such that the capabilities associated with the female gender role have a greater effect on performance than those associated with the male gender role. In addition, while there has not been a comprehensive study of how demographic characteristics would moderate this relationship, it is reasonable to expect that some individual characteristics moderate the relationship.

\section{Method}

\section{Study Sample}

Data were collected from women-owned enterprises within Nairobi, Kenya. Nairobi is the capital city of Kenya, with a representative sample of Kenyan citizens. This city is chosen as it has the most representations of urban entrepreneurs who are the target population. We focused on the formal segment of women entrepreneurs within Nairobi. Women-owned enterprises were defined as businesses owned solely by women or where the woman held at least over $50 \%$ of the ownership (Carter \& Shaw, 2006).

\section{Data Collection}

To get a representative sample, we used multistage cluster sampling. In the first stage, the existing administrative divisions of Nairobi city formed the sampling unit. After numbering the divisions, five divisions were selected using simple random sampling. Since each woman-owned entrepreneurial venture is located in a division, each had an equal chance of being selected for the final sample. The divisions selected from this exercise included Embakasi, Central, Dagoretti, Kibera, and Makadara. In the second stage, the locations within these divisions were considered as the next sampling unit. All locations within these divisions were considered. From these locations a list of formally registered businesses operating in these locations was generated. The actual women-owned entrepreneurial ventures were then selected using a systematic sampling method. We selected 100 women from each of the divisions to achieve a sample size of 500 respondents. We collected primary data from women entrepreneurs through a structured questionnaire.

\section{Measures}

Firm performance. The financial items measured were: return on investments, sales growth, market share, profit-to-sales ratio, and overall financial performance. Previous research suggests that capturing the multidimensionality of small business performance requires the use of multiple measures (Wiklund \& Shepherd, 2005) Subjective financial performance data were collected as described by Dess and Robinson (1984). All financial performance measures asked the respondents to assess firm performance over the last 12 months. The respondents were asked to compare their performance relative to their competitors on a 7-point scale $(1=$ at the bottom of similar firms in the industry to $7=$ at the top of similar firms in the industry). The comparison of firm performance to competitors was 
designed to keep assessments within the same industry and minimize industry effects (Dess, Ireland, \& Hitt, 1990).

Strategic capabilities. The measures of strategic capabilities were adapted from the scales used by Desarbo et al. (2005). Desarbo et al. generated the constructs based on the competitive capability theory by Day (1994) and Conant, Mokwa, and Varadarajan (1990). They found that the items demonstrated convergent validity within related capability and discriminant validity across the capabilities. We modified this instrument for the context and collected data on women entrepreneurs in Nairobi, Kenya (see Appendix 1 for the items.)

Moderating variables. The moderating variables (age, level of education, and experience) were measured through self-reporting of the entrepreneurs. The coding of the categories as well as the frequencies and percentages are shown in Appendix 2 (see Appendix 2 also for demographic profile of respondents.)

Control variables. Control variables in this study included the size and age of the business. Firm size and firm age are important determinants of firm performance (Mukhtar, 2002; Stam \& Elfring, 2008). These were also measured through self-reporting of the entrepreneurs.

In order to test for reliability, we used Cronbach alpha coefficient for capabilities and firm performance. The results of the reliability tests reported in Table 1 indicate the measures are acceptable.

\section{Data Analysis}

Data were analyzed using descriptive and inferential statistics. Descriptive statistics for all study variables were conducted through univariate and frequency procedures. We computed simple bivariate correlation to test whether relationships were in the expected direction. Also, the Pearson product-moment correlations were examined to determine the extent of correlation between the independent and dependent variables, and to assess the potential for multicollinearity (see Table 2.) We used multiple regression analysis to test hypotheses. Specifically, we independently tested the market-linking capabilities, technological capabilities, marketing capabilities, information technological

\section{Table 1}

Reliability Test

\begin{tabular}{lcc}
\hline Variable & Cronbach's Alpha & No of items \\
\hline Marketing capabilities & 0.724 & 6 \\
Market linking capabilities & 0.871 & 4 \\
Management capabilities & 0.652 & 5 \\
Technological capabilities & 0.807 & 6 \\
IT capabilities & 0.843 & 5 \\
Firm performance & 0.868 & 6 \\
\hline
\end{tabular}

Source: Survey Data, 2010 capabilities, and managerial capabilities to determine if they were unique predictors of strategic capabilities. We used epsilon analysis to test the relative importance of the strategic capabilities in predicting performance (LeBreton \& Tonidandel, 2008). This method uses the relative weights of the specific predictors to measure relative importance. To test the moderating effect of demographic characteristics, we performed a moderated hierarchical regression analysis.

\section{Results}

\section{Performance of Women-Owned Entrepreneurial Ventures}

We sought information on firm performance over the last 12 months using return on investments, sales growth, market share, profit to sales ratio, and overall firm performance. We used a descriptive measure of central tendency and dispersion to summarize the responses as tabulated in Table 3

The findings indicate that on average $($ mean $=6$ ), the respondents said that their enterprises had $41-50 \%$ growth on sales, market share, profit to sales ratio, and overall performance in the last 12 months. In addition, a significant number of respondents said that their firms had 51-60\% growth on return on investments in the last 12 months.

\section{Multiple Regression Analysis}

To ascertain whether or not capabilities have a significant effect on firm performance in women-owned entrepreneurial ventures, we employed multiple regression analysis and the results are summarized in Table 4.

Model 1 of Table 4 shows that control variables firm size and firm age have an $\mathrm{R}^{2}$ of .037 and an adjusted $\mathrm{R}^{2}$ of .03 , which implies that the control variables explain $3.3 \%$ variations in overall performance. Model 2, the full model, shows a goodness of fit as indicated by the coefficient of determination $\left(\mathrm{R}^{2}\right)$, with a value of .39 and adjusted $\mathrm{R}^{2}$ of .38 .

This implies that the independent variables (marketing capabilities, market linking capabilities, management capabilities, technological capabilities, and IT capabilities) explain $38 \%$ of the variations of overall performance. The $F$ value of 40.35 indicates that the overall regression model is significant and has some explanatory value. In support of the expectations of the study, the findings indicate that strategic capabilities of women-owned entrepreneurial ventures have a significant influence on firm performance.

Additionally, on the specific strategic capabilities, technological capabilities were found to have a significant effect on firm performance. This finding is similar to a study on internal capabilities and performance by Lee, Lee, and Pennings (2001), which found that technological capabilities are important predictors of firm performance. It can be proposed then that women entrepreneurs need to build their technological capabilities, as they are strong predictors of performance. 
Table 2

\section{Correlation Table}

\begin{tabular}{|c|c|c|c|c|c|c|c|c|}
\hline & 1 & 2 & 3 & 4 & 5 & 6 & 7 & 8 \\
\hline Overall performance & 1 & & & & & & & \\
\hline Firm size & $.200 * *$ & 1 & & & & & & \\
\hline Firm age & .054 & $.203 * *$ & 1 & & & & & \\
\hline Marketing capabilities & $.388 * *$ & $.218 * *$ & 0.093 & 1 & & & & \\
\hline Market-linking capabilities & $.140 * *$ & -0.064 & -0.042 & $.212 * *$ & 1 & & & \\
\hline Management capabilities & $.406 * *$ & 0.04 & 0.059 & $.403 * *$ & $.375 * *$ & 1 & & \\
\hline Technological capabilities & $.493 * *$ & $.152 * *$ & 0.058 & $.331 * *$ & $.119^{*}$ & $.430 * *$ & 1 & \\
\hline IT capabilities & $.534 * *$ & $.151 * *$ & -0.039 & $.404 * *$ & $.179 * *$ & $.594 * *$ & $.514 * *$ & 1 \\
\hline
\end{tabular}

**Correlation is significant at the 0.01 level (2-tailed).

Source: Survey Data (2010)

\section{Table 3}

\section{Performance of Women-Owned Entrepreneurial Ventures}

\begin{tabular}{lcc}
\hline Firm performance & Mean & Std. deviation \\
\hline Return on investments & 6.35 & 1.775 \\
Sales growth & 5.84 & 1.895 \\
Market share & 5.65 & 1.943 \\
Profit to sales ratio & 5.86 & 2.047 \\
Overall financial performance & 6.33 & 1.873 \\
\hline
\end{tabular}

\section{Table 4}

\section{Regression Models}

\begin{tabular}{lcc}
\hline Variables & Model 1 & Model 2 \\
\hline Constant & $55.584(2.011)$ & $27.69(3.862)$ \\
Control variables & $.024(.118)$ & $.025(.425)$ \\
Firm age & $.186(.523)^{* *}$ & $.065(.098)^{* *}$ \\
Firm size & & $.308(.396)^{*}$ \\
Independent variables & & $.25(.349)^{*}$ \\
IT capabilities & & $.056(.596)$ \\
Technological capabilities & & $.145(.435)^{*}$ \\
Management capabilities & & $.017(.371)$ \\
Marketing capabilities & & 40.35 \\
Market-linking capabilities & & .39 \\
F statistics & 8.664 & .38 \\
R $^{2}$ & .037 & .033 \\
Adjusted $\mathrm{R}^{2}$ & & \\
\hline
\end{tabular}

$* \mathrm{P}<.05$

$* * \mathrm{P}<.1$ (2 tailed test)

Values of beta regression coefficients, with standard errors in Parenthesis

Source: Survey Data, 2010

It was further found that marketing capabilities do have a significant effect on firm performance. A study by OderoWanga, Mulu-Mutuku, and Ali-Olubandwa (2009) found that one of the main constraints facing women in the dairy sector in Kenya was lack of marketing skills. Other studies have found a patchy market orientation framework characterized by informal marketing deliberations (Blankson \& Omar, 2002; Van Auken et al., 1994). Van Auken et al. (1994) also noted that women entrepreneurs tend to continue using the same advertising methods they initially used when they started their businesses. This is attributed to limited advertising budgets that prevent them from trying other advertising methods.

In addition, we found that information technological capabilities have a significant effect on firm performance. In support of this finding are studies that have shown that using IT creatively enhances performance and also ensures better cross functional transmission leading to more successful new products and generally improved competitiveness (Bharadwaj, 2000; Bharadwaj, Bhardwaj, \& Konsynski, 1999; Dehning \& Stratopoulos, 2003; Song et al., 2008). In developing economies and Kenya especially, there is an increased use of mobile telephony in small business. Mbogo (2010), in a study of the impact of mobile phone payment on the success and growth of micro business, found that such enterprises in Kenya are increasingly using the mobile technology to facilitate communication and to support transactions in their businesses. For women entrepreneurs, using mobile telephone transactions provides convenience and flexibility as they manage multiple roles in the family and run their business (Komunte, Rwashana, \& Nabukenya, 2012). Management capabilities and market linking capabilities did not have a positive relationship with performance.

\section{Epsilon Analysis}

To test the relative importance of the strategic capabilities, we performed an epsilon analysis (Johnson \& LeBreton, 2004). In this analysis, the estimates derived from the epsilon, often labelled relative weights, sum to the model $\mathrm{R}^{2}$. Thus, the relative weights represent the proportionate contribution each predictor makes to the $\mathrm{R}^{2}$, considering the predictor's direct effects and its effect when combined 


\section{Table 5}

\section{Relative Importance of Strategic Capabilities in Predicting Performance}

\begin{tabular}{lrr}
\hline Strategic capabilities & Raw relative weights & Relative weight as \%R2 \\
\hline Marketing capabilities & .066 & $17.2 \%$ \\
Market linking capabilities & .006 & $1.6 \%$ \\
Management capabilities & .055 & $14.4 \%$ \\
Technological capabilities & .120 & $31.1 \%$ \\
Information technology Capabilities & .137 & $35.7 \%$ \\
Total R & .358 & $100.0 \%$ \\
\hline
\end{tabular}

Source: Survey Data (2010)

with other predictors. Future studies can also calculate the percentage of $\mathrm{R}^{2}$ explained by each predictor.

The results from this analysis as indicated in Table 5 show that the most important strategic capabilities are the information technology capabilities and technological capabilities that account for $36 \%$ and $31 \%$ of the total explained $\mathrm{R}^{2}$, respectively. This is followed by marketing capabilities explaining $17 \%$ and management capabilities explaining $14 \%$ of the total explained $\mathrm{R}^{2}$. We noted that market-linking capabilities explain only $2 \%$ of the total explained $\mathrm{R}^{2}$.

This is an interesting finding because the three capabilities that have the greatest influence are those which, according to the social role theory, are more associated with the male gender stereotype. The market linking capabilities that are associated with the female gender role as implied by the social role theory is the least important in explaining the total $\mathrm{R}^{2}$. This could possibly explain why women-owned enterprises do not perform well. The capabilities associated with the female stereotype as postulated by the social role theory do not have a significant relationship to firm performance.

\section{Moderating Effect}

To determine the moderating effect the demographic factors (experience, age, and level of education) have on the relationship between strategic capabilities and performance in women-owned entrepreneurial ventures, a moderated hierarchical regression analysis was performed. This involved running initial regressions with the control variables. Regressions with only main effects followed, and finally the hypothesized interactions were entered. To minimize the effect of multicollinearity, the independent variables were mean-centred and converted to z-scores within each variable (Aiken \& West, 1991). We used the SPSSS program for this conversion.

Experience moderation. The results in Table 6, models 1 to 7 show a goodness of fit as indicated by the coefficient of determination $\left(\mathrm{R}^{2}\right)$ with a value of $0.033,0.044$, $0.34,0.341,0.34,0.34$, and 0.34 . There was a significant main effect of experience of respondents on firms' overall performance $(\beta=0.074, \mathrm{P}<0.1)$. It was noted however, that the interaction effect of experience and the strategic capabilities as shown in model 7 were positive but not significant. This implies that experience does not moderate the relationship between capabilities and performance. This is consistent with other studies (Acar, 1993) and could be because most women in the sample had been in business for less than five years and for most this was their first business. On the other hand, the direct effect of experience on performance was significant. These results support earlier research by Brush and Hisrich (1991) that found that previous experience was associated with performance.

Age moderation. The results shown in Table 7, models 1 to 7 show a goodness of fit as indicated by the coefficient of determination $\left(\mathrm{R}^{2}\right)$. There was a significant and negative effect on the age of respondents on the firms' overall performance $\left(\beta=-.0 .094 \mathrm{P}<0.05 ; \mathrm{R}^{2}\right.$ Change $\left.=.002\right)$. It was also noted that the interaction of age and the strategic capabilities had an $\mathrm{R}^{2}$ change of 0.003 and are significant at $5 \%$. This implies that, although negatively, age does moderate the relationship between strategic capabilities and firm performance in women-owned enterprises. It infers therefore that as age increases, performance decreases. The possible explanation for this is that as women age, their capabilities in the various functional areas decrease.

Since the moderating effect of age was significant, we plotted interactions and examined the first-order effects of the independent variables to facilitate interpretation. Figure 1 and 2 show the moderating effect of age on information technology capabilities and marketing capabilities. Figure 1 illustrates that when age is high it has a negative effect on the relationship between IT capabilities and firm performance. When age is low, performance increases.

The explanation for this could be that as one ages, one may not be as apt to embrace new technology or adopt new marketing strategies, which thus affects performance negatively. Longowitz and Minniti (2007) found that for women, the most entrepreneurially active age was between 25 and 34 years. The findings of this study indicate that age negatively moderated the relationship between strategic capabilities and firm performance. Gathenya, Bwisa, and Kihoro (2011) found that beyond the "entrepreneurial age," female entrepreneurs seek more stable enterprises and become more conservative. They add that this may also apply 


\section{Table 6}

\section{Experience Moderation}

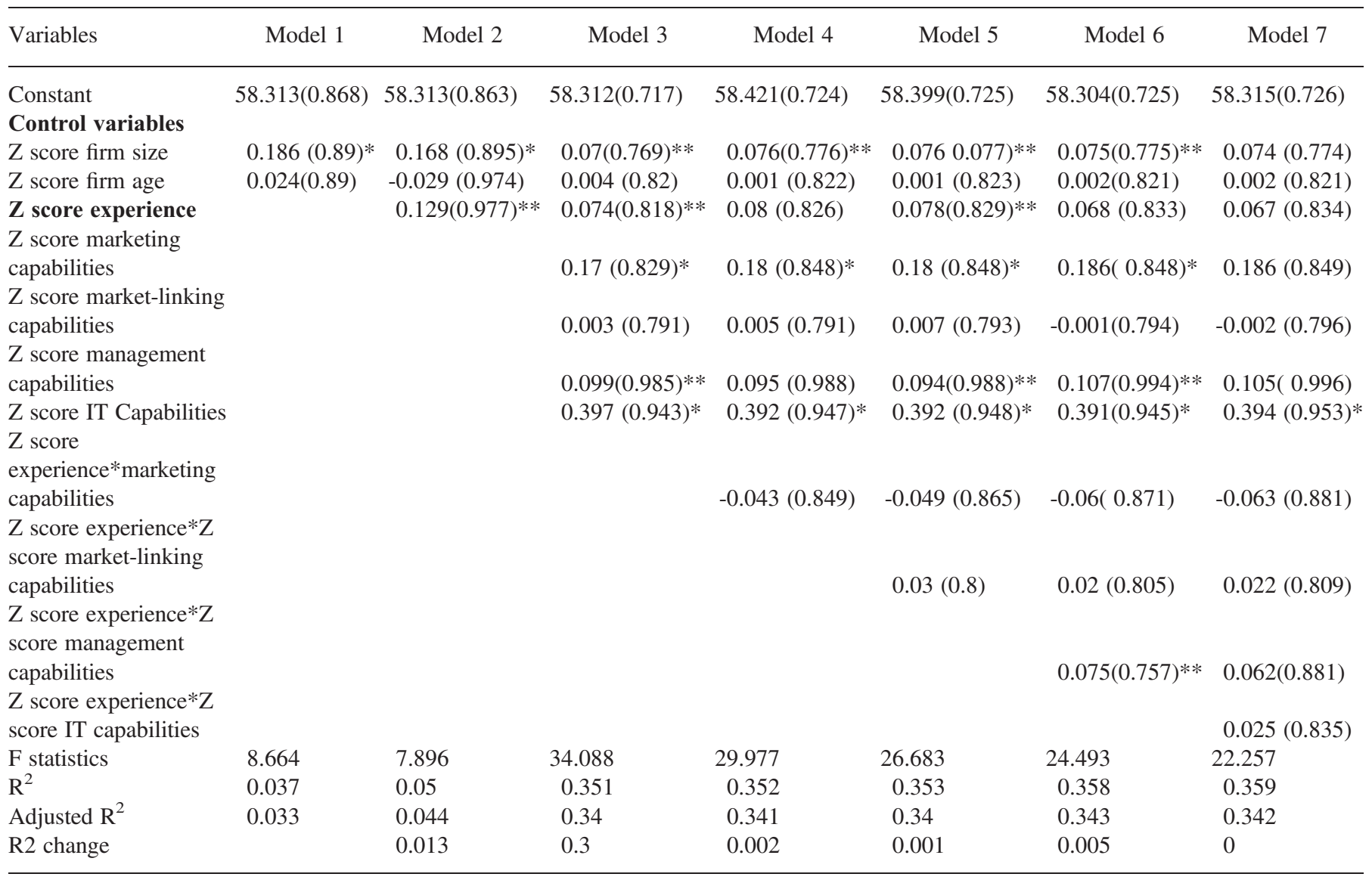

Values of standardized beta coefficients, with standard errors in Parenthesis

$* \mathrm{p}<.05$

$* * \mathrm{p}<0.1$ (2 tailed test)

Survey Data (2010)

for women who for various reasons (such as cultural and economic reasons) may have reduced access to new management styles, new ways of doing things, and to new technology. This finding is also supported by UNCTAD (United Nations Conference on Trade and Development, 2001).

Education moderation. From the results shown in Table 8, models 1 to 7 show a goodness of fit as indicated by the coefficient of determination $\left(\mathrm{R}^{2}\right)$ with values between .033 and 0.341 . The main effect for level of education as well as the interaction of education and the strategic capabilities was not significant and had no effect on the $\mathrm{R}^{2}$. This implies that level of education does not have a significant effect on the relationship between strategic capabilities and firm performance.

Contrary to our expectations and previous research in developed countries, level of education level was not significant and did not have a moderating effect on the relationship between capabilities and performance. However, this finding is similar to a previous study conducted by Lerner et al. (1997) among Israeli women entrepreneurs to establish factors influencing performance.
The study found that education level was not related to performance; however, the entrepreneurs studied all had higher levels of education. Similarly, the women we sampled had received at least a secondary-level education. Therefore, there was not enough differentiation in education to find performance correlations.

From the results above we therefore note that of the three demographic variables that were hypothesized as moderating variables, only age significantly moderated the relationship between strategic capabilities and performance in women-owned entrepreneurial ventures.

\section{Discussion}

\section{Summary}

The relationship between strategic capabilities and firm performance in women-owned entrepreneurial ventures in Kenya was empirically examined in this study. Results of 


\section{Table 7}

\section{Age Moderation}

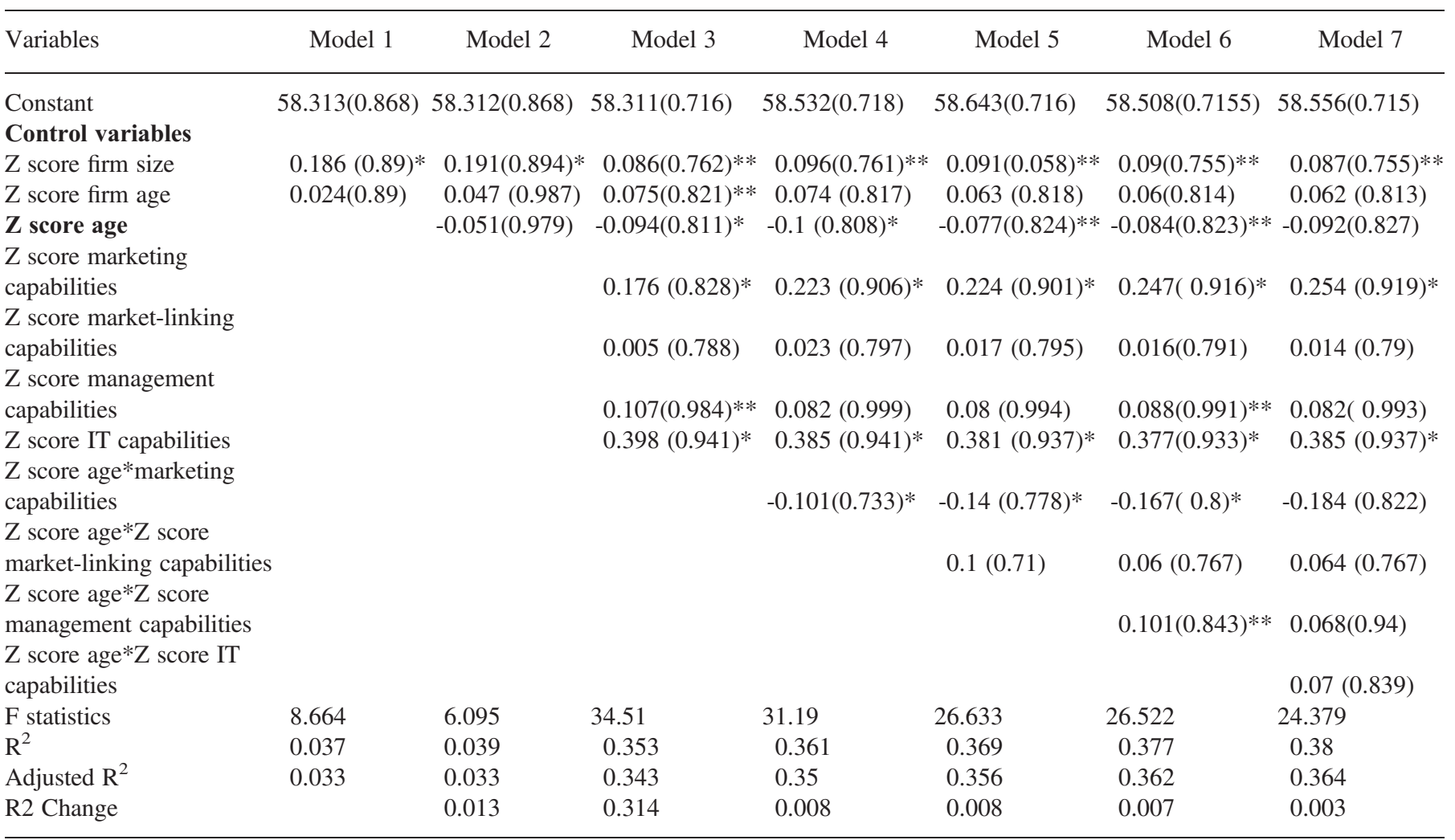

Values of standardized beta coefficients, with standard errors in Parenthesis

$* \mathrm{p}<.05$

$* * \mathrm{p}<0.1$ (2 tailed test)

Survey Data (2010)

this study provided support for the hypotheses linking strategic capabilities to performance. Building on the RBV and the capability framework theory, we contend that strategic capabilities do have positive effects on firm performance.

Figure 1. The moderating effect of age on the relationship between IT capabilities and firm performance

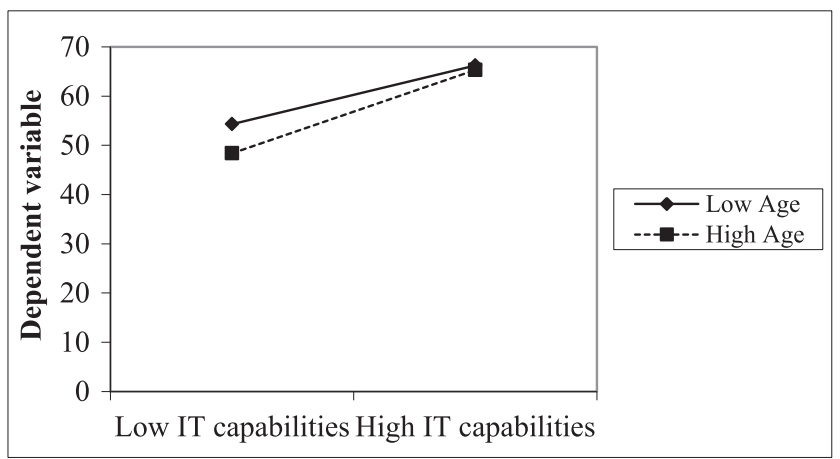

More importantly, information technology, marketing, and technological capabilities were found positively and significantly related to performance. However, management and market-linking capabilities, which according to the social

Figure 2. The moderating effect of age on the relationship between marketing capabilities and firm performance

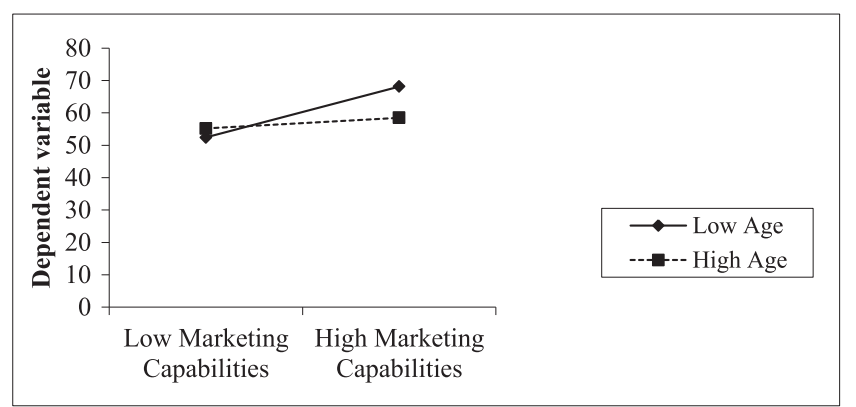




\section{Table 8}

\section{Education Moderation}

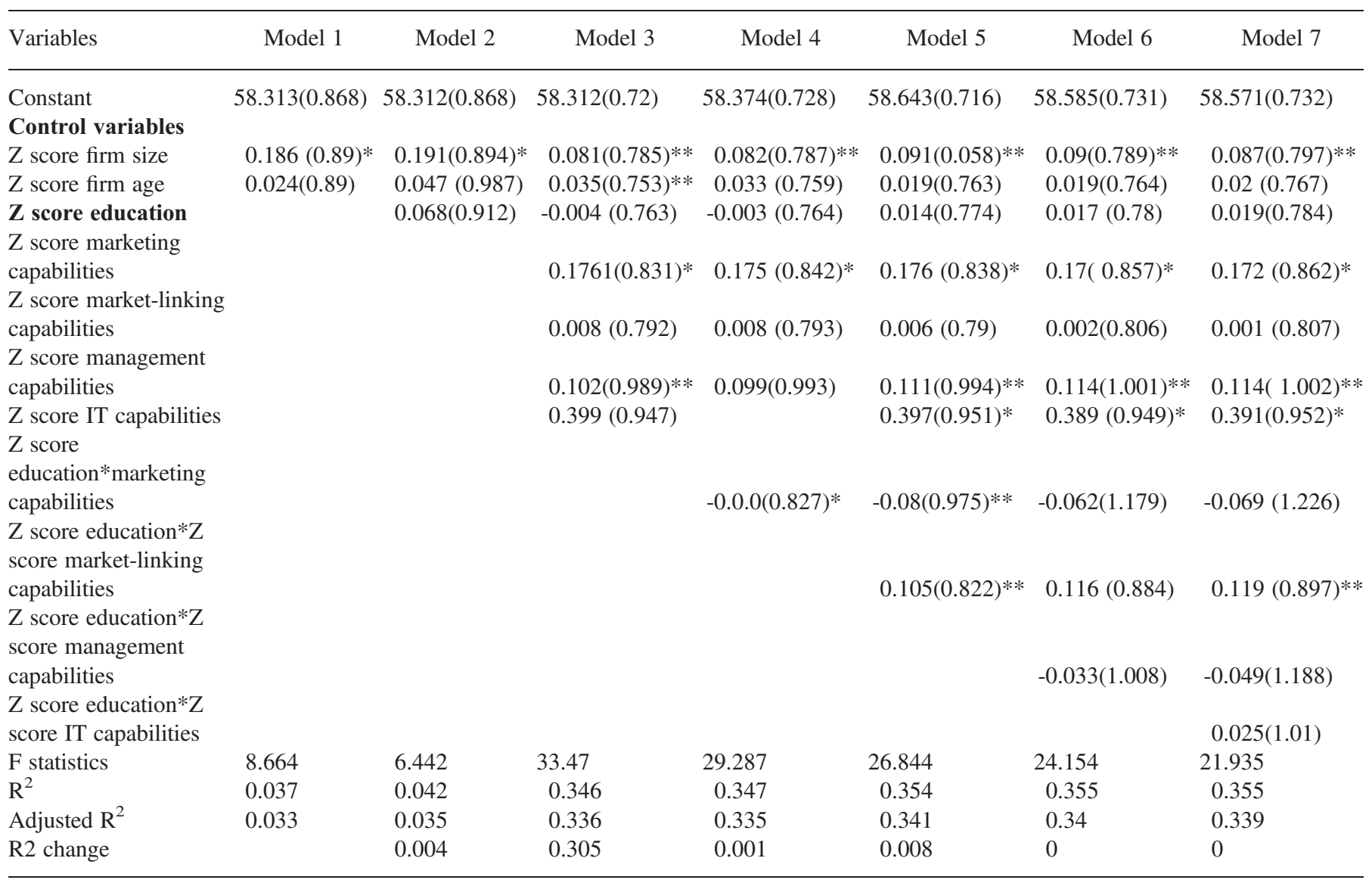

Values of standardized beta coefficients, with standard errors in Parenthesis

$* \mathrm{p}<.05$

$* * \mathrm{p}<0.1$ (2 tailed test)

Survey Data (2010)

theory should be more associated with the female gender, were not significant. For the moderating variables, although negatively, age was found to significantly moderate the relationship between strategic capabilities and firm performance in women-owned entrepreneurial ventures.

\section{Contributions to Scholarship}

This study contributes to our understanding of the relationship between strategic capabilities and firm performance in small, women-owned enterprises in two important ways. First, there have been relatively few studies conducted on women-owned enterprises in developing economies. For countries such as Kenya, women's ability to contribute to the economic development in times of such great social change is key to the country's future success. Most research on strategic capabilities, small firm success, and gender differences has been conducted in developed economies or China. This study brings these three topics into a context that has been largely ignored.
Second, the results are surprising: social theory tells us there are certain gender specific stereotypes and that success is often closely associated with the fit between people and organizations. These results indicate that women entrepreneurs who are stronger in "male" capabilities have better performance outcomes, which we did not expect and which lead to important considerations for future research.

\section{Applied Implications}

The implication of these findings therefore is that, for women to improve the performance of their businesses, they must build on their information technology, marketing, and technological capabilities. We therefore recommend designing training and development programs for women entrepreneurs that target the development of specific capabilities that influence performance. In addition, women should be encouraged to join associations that enable them build their capabilities. Lerner and Almor (2002) found that women 
who were involved and registered in business associations performed better than those not involved in such associations. Participation in these associations exposes women entrepreneurs to opportunities and knowledge that enhances their capabilities. Thirdly, facilitation is needed so that women access credit that would enable them to acquire necessary technology. We recommend that the provision of credit be tied to appropriate training that would allow women to convert the acquired resources to capabilities and add value. Resources themselves do not confer advantage but how resources are used to create core competencies would make a difference in performance. Fourthly, as age was found to have a negative and significant effect on performance, we recommend that women entrepreneurs be encouraged to regularly undertake training on the various facets of capabilities to ensure that they remain relevant and build capabilities that would enable their businesses to do well, especially those that relate to technology, information technology, and marketing.

\section{Limitations and Future Research Directions}

Since this study focused only on women entrepreneurs in general, comparative studies should examine both successful and unsuccessful women entrepreneurs to gain further insight on the effect of strategic capabilities on firm performance. Additionally, the study could also be extended to the male entrepreneurs with comparisons drawn. It would be insightful to establish and compare the relative importance of strategic capabilities in male-owned entrepreneurial ventures and their impact on performance. Finally, while we examined women entrepreneurs at one point in time, a longitudinal time span would provide more insight on women entrepreneurs and how they build their capabilities over time.

\section{JEL Classification: M10}

\section{References}

Acar, A. (1993). The Impact of Key Internal Factors on Firm Performance: AnEmpirical Study of Small Turkish Firms. The Journal of Small Business Management, (Oct), 31(4), 86-92.

Aiken, L.S., \& West, S.G. (1991). Multiple regression testing and interpreting interractions. Thousand Oaks, CA: Sage

Barney, J. (1991). Firm Resources and Sustained Competitive Advantage. Journal of Management, 17(1), 99-120.

Bharadwaj, A.S. (2000). A resource-based perspective on information technology capability and firm performance: An empirical study. MIS Quarterly, 24(1), 169-196.

Bharadwaj, A.S., Bhardwaj, S.G., \& Konsynski, B.R. (1999). Information technology effects on firm performance as measured by Tobin's q. Management Science, 45(7), 1008-1024.
Birley, S. \& Norburn, D. (1987) Owners and managers: The venture 100 versus the Fortune 500. Journal of Business Venturing 2(4), 351-363.

Blankson, C., \& Omar, O.E. (2002). Marketing practices of African and Caribbean small businesses in London, UK. Qualitative Market Research: An International Journal, 5(2), 123-134.

Boohene, R. (2009). The relationships among Gender, Strategic Capabilities, and Performance of Small Retail Firms in Ghana. Journal of African Business, 10,121-138.

Box, T.M., Watts, L.R., \& Hisrich, R.D. (1994). Manufacturing entrepreneurs: An empirical study of the correlates of employment growth in the Tulsa MSA and rural East Texas. Journal of Business Venturing, 9(3), 261-270.

Box, T.M., White, M.A., \& Barr, S.H. (1993). A Contingency Model of New Manufacturing Firm Performance. Entrepreneurship: Theory and Practice, 18(2), 31-46.

Brush, C. (1992).Research on women business owners: Past trends a new perspective and future directions. Entrepreneurship: Theory and Practice, 16(4), 393-407.

Brush, C., Carter, N., Gatewood, E., Green, P., \& Hart. M. (2004). Clearing the hurdles: Women building high-growth enterprises. New York: Financial Times/Prentice Hall

Brush, G., \& Cooper, S.Y. (2012). Female entrepreneurship and economic development: an international perspective. Entrepreneurship and Regional Development, 24(1-2), 1-6

Brush, C.G., \& Hisrich, R.D. 1991. Antecedent influences on women-owned businesses. Journal of Management Psychology, 6(2), 9-16.

Carlson, G. \& Karlsson, K. (1970). Succession and performance among school superintendents. American Sociological Review, 35, 710-718

Carter, N.M., \& Allen, K.R. (1997). Size determinants of women-owned businesses: Choice or barriers to resources? Entrepreneurship and Regional Development, 9, 211-220.

Carter, S., \& Shaw, E. (2006). Women's business ownership: Recent research and policy developments: Report to the Small Business Service.

Catley, S., \& Hamilton, R. (1998). Small business development and gender of owner. Journal of Management Development, 17(1), $75-82$.

Cejka, M.A., \& Eagly, A.H. (1999), Gender-stereotypic images of occupations correspond to sex segregation of employment. Personality and Social Psychology Bulletin, 25(4), 413-423.

Celuch, K., \& Murphy, G. (2010). SME Internet use and strategic flexibility: the moderating effect of IT market orientation. Journal of Marketing Management, 26(1-2), 131-145.

Chandler, G.N., \& Jensen, E. (1992). The founder's self-assessed competence and venture performance. Journal of Business Venturing, 7(3), 223-236.

Conant, J.S., Mokwa, M.P., \& Varadarajan, P.R. (1990). Strategic types, distinctive marketing competencies and organizational performance: A multiple measures-based study. Strategic Management Journal, 11, 365-383.

Cooper, A.C. (1981). Strategic management: new ventures and business performance. Long Range Planning, 14(5), 39-45.

Daneels, E. (2008). Organizational antecedents of second-order competences. Strategic Management Journal, 29(5), 519-543.

Day, G.S., \& Wensley, R. (1988). A framework for diagnosing competitive superiority. The Journal of Marketing, 52(2), $1-20$. 
Day, G.S. (1990). Marketing's contribution to the strategy dialogue. Journal of the Academy of Marketing Science, 20(4), 323-329.

Day, G.S. (1994). The capabilities of market-driven organizations. Journal of Retailing, 58, 37-52.

Day, G.S. (2000). Managing market relationships. Journal of the Academy of Marketing Science, 28(1), 24-30.

De Bruin, A., Brush, C.G., \& Welter, F. (2007). Advancing a framework for coherent research on women's entrepreneurship. Entrepreneurship: Theory and Practice, 31(2), 323-339.

Dehning, B., \& Stratopoulos, T. (2003) Determinants of a sustainable competitive advantage due to an IT-enabled strategy. Journal of Strategic Information Systems, 12, 7-28.

Desarbo, W.S., Di Benedetto, C.A., Song, M. \& Sinha I. (2005). Revisiting the miles and snow framework: Uncovering interrelationships between the strategic types, capabilities, environmental uncertainty, and firm performance. Strategic Management Journal, 26, 47-74.

Dess, G.G., Ireland, R.D., \& Hitt, M.A. (1990). Industry effects and strategic management research. Journal of Management, 16(1), 7-27.

Dess, G.G. \& Robinson, R.B. (1984). Measuring organizational performance in the absence of objective measures: The case of the privately-held firm and conglomerate business unit. Strategic Management Journal, 5(3), 265-273.

Dolinski, A.L., Caputo, R.K., Pasumaty, K., \& Quanzi, H. (1993). The effects of education on business ownership: A longitudinal study of women entrepreneurship. Entrepreneurship Theory and Practice, Fall, 43-53.

Eagly, A.H. (2007). Female Leadership advantage and Disadvantage: Resolving the contradictions. Psychology of Women Quarterly, 31, 1-12.

Eagly, A.H. \& Wood, W. (1999). The origins of sex differences in human behaviour-Evolved dispositions versus social roles. American Psychologist, 54(6), 408-423.

Eagly. A. (1987). Sex differences in social behaviour. A social-role interpretation, Hillsdale, NJ: Erlbaun

Eisenhardt, K.M., \& Martin, J.A. (2000). Dynamic capabilities: What are they? Strategic Management Journal, 1(10/11), 1105-1121.

Fairlie, R.W. \& Robb, A.M. (2009). Gender differences in business performance evidence from the characteristics of business owners' survey. Small Business Economics, 33, 375-395.

Fuentes-Fuentes, M., Bojica, A., Ruiz-Arroyo, M., \& Welter, F. (2015). Innovativeness and Business relationships in womenowned firms: The role of gender stereotypes. Canadian Journal of Administrative Sciences. DOI: 10.1002/CJAS.1329

Gathenya, J.W., Bwisa, H.M., \& Kihoro, J.M. (2011). Interaction between Women Entrepreneurs' Age and Education on Business Dynamics in Small and Medium Enterprises in Kenya. International Journal of Business and Social Science, August 2(15), $265-272$

Hambrick, D.C. \& Mason, P.A. (1984). Upper echelons: The organization as reflection of its top managers. Academy of Management Review, 9(2) 193-206

Heffernan, M. (2003). Changing the game. Prowess Conference, $1-15$

Hisrich, R., Brush, C., Good, D., \& DeSouza, G. (1997). Performance in entrepreneurial ventures: Does gender matter. Frontiers of Entrepreneurship Research, 238-239.
Idris, A. (2009). Management styles and innovation in womenowned enterprises. African Journal of Business Management, 3(9), 416-425.

Jennings, J.E. \& Brush, C.G. (2013). Research on women entrepreneurs: Challenges to (and from) the broader entrepreneurship literature? Academy of Management Annals, 7, 661-713

Johnson, J.W. \& LeBreton, J.M. (2004). History and use of relative importance indices in organizational research. Roganizational Research Methods, 7(3), 238-257.

Kallenberg, A.L., \& Leicht, K.T. (1991). Gender and organizational performance: Determinants of small business survival and success. Academy of Management Journal, 34(1), 136-16.

Kelley, D., Brush, C., Greene, P., \& Litovsky (2013). Global Entrepreneurship Monitor: 2012 Women's Report. Wellesley, MA: Global Entrepreneurship Research Association, Babson College.

Kohli, A.K., Jaworski, B.J., \& Kumar, A. (1993). A Measure of market Orientation. Journal of Marketing Research, 30(4), 467-477.

Komunte, M., Rwashana, A.S., \& Nabukenya, J. (2012). Comparative analysis of mobile phone usage among women entrepreneurs in Uganda and Kenya. African Journal of Computing and ICT, 5(5), 74-86.

Lado, A.A., Boyd, N.G., \& Wright, P. (1992). A competency-based model of sustainable competitive advantage: Toward a conceptual integration. Journal of Management, 18, 77-91.

LeBreton. J.M. \& Tonidandel. S. (2008). Multivariate relative importance: extending relative weight analysis to multivariate criterion spaces. Journal of Applied Psychology, 93(2), 329-345

Lee, C., Lee, K., \& Pennings, J.M. (2001). Internal capabilities, external networks, and performance: A study on technologybased ventures. Strategic Management Journal, 22, 615-664.

Lerner, M. \& Almor, T. (2002). Relationships among strategic capabilities and the performance of women-owned small ventures. Journal of Small Business Management, 40(2), 109-125.

Lerner, M., Brush, C.G. \& Hisrich, R.D. (1997). Israeli women entrepreneurs: An examination of factors affecting performance. Journal of Business Venturing, 12(4), 315-334.

Longowitz, N. \& Minniti, M. (2007). The Entrepreneurial Propensity of Women. Entrepreneurship: Theory and Practice, 31(3), 341-364

Loscocco, K.A., \& Robinson, J. (1994). Barriers to women's small business success in the U.S. Gender and Society, 5(4), 511-532.

Mbogo, M. (2010). The impact of mobile payments on the success and growth of micro-business: The case of M-Pesa in Kenya. The Journal of Language, Technology and Entrepreneurship in Africa, 2(1): ISSN 1998-1279.

Mukhtar, S. (2002). Differences in male and female management characteristics. A study of owner-manager businesses. Small Business Economics, 18(4), 289-310.

Mungai, E.S., \& Ogot, M. (2012). Gender, Culture and Entrepreneurship in Kenya. International Business research, 5(5), $175-183$.

Newbert, S.L. (2007). Empirical research on the resource-based view of the firm: An assessment and suggestions for future research. Strategic Management Journal, 28(2), 121-146. 
Nuevo, S., \& Wade, M.R. (2010). The formation and value of it-enabled resources: antecedents and consequences of synergistic relationships. MIS Quarterly, 34(1), 163-183.

Odero-Wanga, D., Mulu-Mutuku, M., \& Ali-Olubandwa, A. (2009). Value added milk products: Constraints to women in milk micro enterprises in Kenya. Journal of Development and Agricultural Economics, 1(7), 144-149.

Orser, B., \& Hogarth-Scott, S. (2002). Opting for growth: Gender Dimensions of choosing enterprise development. Canadian Journal of Administrative Sciences, 19(3), 284-300

Peltier, J.W., Schibrowsky, J.A., \& Zhao, Y. (2009). Understanding the antecedents to the adoption of CRM technology by small retailers. International Small Business Journal, 27(3), 307-336.

Podsakoff, P.M., Mackenzie, S.B., Moorman, R.H., \& Fetter, R. (1990). Transformational leader behaviours and their effects on followers' trust in leader, satisfaction, and organizational citizenship behaviours. Leadership Quarterly, 1(2), 107-142.

Powell, M., \&Ansic, D. (1997). Gender differences in risk behaviour in financial decision-making: An experimental analysis. Journal of Economic Psychology, 18, 605-628.

Reijonen, H., \& Komppula, R. (2010). The adoption of market orientation in SMEs: required capabilities and relation to success. Journal of Strategic Marketing, 18(1), 19-37.

Rosa, P., Carter, S., \& Hamilton, D. (1996). Gender as a determinant of small business performance. Insights from a British study. Small Business Economics, 8, 463-478.

Saffu, K., Aporu S.O., Elijah-Mensa. \& Ahumatah, J. (2008). The contribution of human capital and resource-based view to small- and medium-sized tourism venture performance in Ghana. International Journal of Emerging Markets, 3(3), 268-284

Selznick, P. (1957). Leadership in administration. New York: Harper \& Row.

Song, M., Nason, R.W., \& Di Benedetto, C.A. (2008). Distinctive marketing and information technology capabilities and strategic types: A cross-national investigation. Journal of International Marketing, 16(1), 4-38.

Stam, W. \& Elfring, T. (2008). Entrepreneurial orientation and new venture performance: The moderating role of intra- and extraindustry social capital. Academy of Management Journal, 51(1), 97-111.

Stevenson, L. (1990). Some methodological problems associated with researching women entrepreneurs. Journal of Business Ethics, 9, 439-446.

Tandon, N. (2002). E-commerce training with small-scale entrepreneurs in developing countries: some findings. http://www. networkedintelligence.com/presentation for UNCTA commerce strategies for development

Teece, J.D., Pisano, G., \& Shuen, A. (1997). Dynamic capabilities and strategic management. Strategic Management Journal, 18(7), 509-533.

UNCTAD (United Nations Conference on Trade and Development) (2001). An Assessment of the Growth of Women Entrepreneurs in Sub-Saharan Africa. Working paper. USA, New York

Van Auken, H.E., Rittenburg, B.T.L., Doran, M. \& Hsieh, S. (1994). An empirical analysis of advertising by women entrepreneurs. Journal of Small Business Management, 32(3), 10-28

Verheul, I., Van Stel, A., \& Thurik, R. (2006). Explaining male and female entrepreneurship at country level. Entrepreneurship and Regional Development: An International Journal, 18(2), 151-183.

Wiklund, J., \& Shepherd, D. (2005). Entrepreneurial orientation and small business performance. Journal of Small Business Venturing, 20, 71-91

Yusuf, A. (1995). Critical success factors for small business: Perceptions if South Pacific entrepreneurs. Journal of Small Business Management, 33(2), 68

Zahra, S.A., Sapienza, H.J., \& Davidsson, P. (2006). Entrepreneurship and dynamic capabilities. A review, model and research Agenda. Journal of Management Studies, 43, 4.

\section{Appendix 1: Sample of capabilities}

Please evaluate how well or poorly you believe that your business performs the specific activities or possesses the specific capabilities relative to your major competitors. $(0=$ "much worse than your competitors" to $10=$ "much better than your competitors")

\begin{tabular}{|c|c|c|}
\hline \multirow{5}{*}{$\begin{array}{l}\text { Marketing } \\
\text { Capabilities: }\end{array}$} & $\begin{array}{l}\text { Knowledge of } \\
\text { customers }\end{array}$ & $\begin{array}{l}\text { Combining of } \\
\text { marketing activities }\end{array}$ \\
\hline & $\begin{array}{l}\text { Knowledge of } \\
\text { competitors }\end{array}$ & $\begin{array}{l}\text { Effectiveness of } \\
\text { marketing programs }\end{array}$ \\
\hline & $\begin{array}{l}\text { Skill of dividing and } \\
\text { targeting the market }\end{array}$ & $\begin{array}{l}\text { Effectiveness of } \\
\text { advertising programs }\end{array}$ \\
\hline & $\begin{array}{l}\text { Capabilities in creating } \\
\text { and managing durable } \\
\text { customer relationships }\end{array}$ & \\
\hline & $\begin{array}{l}\text { Ability to retain } \\
\text { customers }\end{array}$ & Capabilities in \\
\hline \multirow{5}{*}{$\begin{array}{l}\text { Market- } \\
\text { linking } \\
\text { Capabilities: }\end{array}$} & Relationships with & creating durable \\
\hline & channel members & relationships \\
\hline & (whole-sellers, retailers) & with our suppliers \\
\hline & $\begin{array}{l}\text { Financial management } \\
\text { skills }\end{array}$ & $\begin{array}{l}\text { Market planning } \\
\text { process }\end{array}$ \\
\hline & Cost control capabilities & Human resource \\
\hline \multirow[t]{3}{*}{$\begin{array}{l}\text { Management } \\
\text { Capabilities: }\end{array}$} & $\begin{array}{l}\text { Accuracy of profitability } \\
\text { and revenue }\end{array}$ & $\begin{array}{l}\text { management } \\
\text { capabilities }\end{array}$ \\
\hline & $\begin{array}{l}\text { New product } \\
\text { development capabilities } \\
\text { Quality control skills }\end{array}$ & $\begin{array}{l}\text { Integrated logistics } \\
\text { systems }\end{array}$ \\
\hline & Ability of predicting & Cost control \\
\hline \multirow{3}{*}{$\begin{array}{l}\text { Technological } \\
\text { Capabilities }\end{array}$} & technological changes & capabilities \\
\hline & $\begin{array}{l}\text { in the industry } \\
\text { IT systems for internal } \\
\text { communication }\end{array}$ & Production facilities \\
\hline & $\begin{array}{l}\text { IT systems for } \\
\text { facilitating market } \\
\text { knowledge creation }\end{array}$ & $\begin{array}{l}\text { IT systems for } \\
\text { facilitating market } \\
\text { knowledge creation }\end{array}$ \\
\hline$I T$ & IT systems for external & IT systems for new \\
\hline Capabilities: & communication & product development \\
\hline
\end{tabular}




\section{Appendix 2: Profiles of women entrepreneurs included in study}

Variable (Coding)

Frequency Percentage

\section{Age}

$18-24(1)$

25-34 (2)

$35-44$ (3)

45-54 (4)

55-64 (5)

Over 65 (6)

Highest Level of Education Attained

O-Level (1)

Professional qualification (2)

Diploma (3)

First Degree (4)

Post Graduate Degree (5)

Primary Level (6)

Ownership of the Business

Sole Owner (100\%ownership) (1)

Majority Shareholder (over 50\%) (2)

Equal Shareholder (50\% share) (3)

Minority Shareholder (less than 50\%) (4)
Appendix 2

(Continued)

Variable (Coding)

Frequency Percentage

Number of Employees of the Firm

$<=.00(1)$

$1-20.00(2)$

21-40 (3)

41-60 (4)

$60+(5)$

Years of Experience

0 -2years (1)

3-5years (2)

6-9years (3)

$10-15$ years $(4)$

16-20years (5)

Over 20 years (6)

Duration of the Respondent in Business

Less than 1 year (1)

1-2years (2)

3-5years (3)

Over 5 years (4)

$126 \quad 28.0$

$306 \quad 68.0$

$15 \quad 3.3$

$\begin{array}{ll}2 & 0.4\end{array}$

$1 \quad 0.2$

$105 \quad 23.3$

$139 \quad 30.9$

$92 \quad 20.4$

$50 \quad 11.1$

$7 \quad 1.6$

$9 \quad 2.0$

Source: Survey Data (2010) $\begin{array}{ll}35 & 7.8\end{array}$

$87 \quad 19.3$

$147 \quad 32.7$

$181 \quad 40.2$

(Continues) 